\title{
Unraveling Sediment Transport Along Glaciated Margins (the Northwestern Nordic Seas) Using Quantitative X-Ray Diffraction of Bulk ( $<2 \mathrm{~mm}$ ) Sediment
}

\author{
J.T. Andrews \\ Institute of Arctic and Alpine Research \\ and Department of Geological Sciences, \\ University of Colorado, Boulder \\ USA
}

\section{Introduction}

In most environments, sediment transport is controlled by the density and velocity of the transporting medium, and the grain-size of the sediment. Thus in a very simplistic sense, transport by wind and/or water results in a settling of grains and invariably sediments become more fine-grained along the transport path. Major exceptions to this rule are those areas where sediment is entrained and transported by sea ice or icebergs. In these polar and sub-polar areas the normal rules of sediment transport do not apply. Hence, coarse-grained sediments can be, and have been, transported 100's to 1000's of kilometers beyond their point of entrainment in sea ice or a glacier/ice stream. However, a critical but frequently overlooked aspect of sediment transport is that of provenance. On-land, the sources of sediment delivered to a stream channel are essentially known as they are delimited and restricted mineralogically to the bedrock that outcrops within the drainage basin (Eberl, 2004). The marine environment, and especially the glacial marine environment, is much more open, so that abrupt changes in sediment transport from different bedrock outcrops are not uncommon. An obvious example is that of the major changes in sediment provenance associated with the North Atlantic Heinrich $(\mathrm{H}-)$ events of the last glacial cycle, which involved massive discharges of melt-water and icebergs transported from the Hudson Strait ice stream of the Laurentide Ice Sheet (Heinrich, 1988; Andrews and Tedesco, 1992; Bond et al., 1992; MacAyeal, 1993; Dowdeswell et al., 1995; Hesse, 1995; Andrews, 1998; Hemming, 2004). These large-scale glaciological events resulted in the transport of massive amounts of glacially derived detrital carbonate into the North Atlantic, which were then transported as far east as the margins of Portugal and the British Isles (Lebreiro et al., 1996; Peck et al., 2007).

A variety of methods have been used to distinguish changes in the transport and provenance of glacial marine sediments. These have included studies of the mineralogy and characteristics of the sand-size fraction (Bond et al., 1997), radiogenic isotopic signatures that 
allow identification of the probable bedrock outcrops (Grousset et al., 1993, 2001; Farmer et al., 2003; Verplanck et al., 2009), argon ages which allow a source identification (Hemming et al., 2002a; 2002b), magnetic properties (Pirrung et al., 2002; Andrews and Hardardottir, 2009), sediment reflectance (Ortiz, 2009), and quantitative X-ray diffraction (qXRD) of the bulk sediment ( Moros et al., 2004; Andrews and Eberl, 2007). It is the purpose of this paper to show how qXRD is a relatively cheap, simple, but powerful approach to determine changes in sediment provenance, hence sediment transport, along the glaciated margin of E/NE Greenland and across the Denmark Strait to Iceland.

\section{Background}

The area of Denmark Strait is a contact zone between southward flowing Polar/Arctic water masses sourced from the Arctic Ocean (East Greenland Current and East Iceland Current) and warmer, more saline northward flowing Atlantic Water (Irminger and North Iceland Irminger Current) (Stefansson, 1962; Malmberg, 1985; Hopkins, 1991) (Fig. 1). Sea ice is pervasive on the East Greenland shelf and in many years also extends onto the NW and N Iceland shelf (Fig. 1), but only during extreme years does the ice wrap around Iceland and impact the E/SW coasts (Gray, 1881a; Ogilvie, 1996). This SW-NE pattern of sea ice extent in the Nordic Seas (Fig. 1) also appears as a feature of the LGM (Li et al., 2010). Ocean fronts form at the contact between the Polar and Atlantic water masses and define the North Iceland Front and the Polar Front (Fig. 2). These fronts are often areas of high marine productivity (Jennings et al., 2011) and they also mark boundaries between low to higher rates of drift ice melt, hence sites of enhanced sediment deposition.

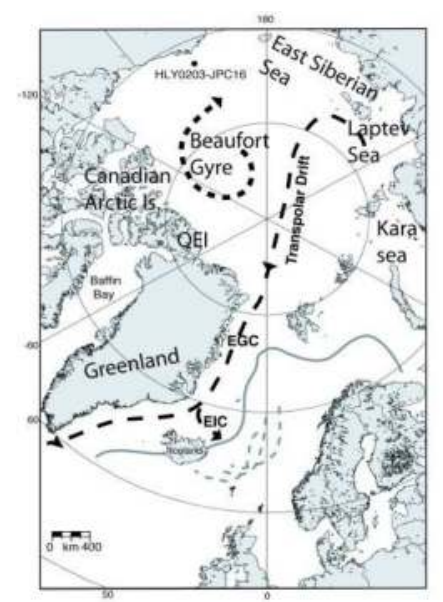

Fig. 1. Location of research area showing the major surface currents---TransPolar Drift, East Greenlany.

Icebergs calved from tidewater margins of E/NE Greenland ice streams (Fig. 3) are frequently retained within the fjords for months to years because of the presence of sikkussuaq and land-fast sea ice (Dwyer, 1995; Syvitski et al., 1996; Reeh et al., 2001). Thus during summers, when there is little or no removal of the land-fast sea ice, iceberg sediment transport is severely curtailed and the bulk of the deposition will take place within the fjord 
(Reeh et al., 1999; Mugford and Dowdeswell, 2010). Conversely, during warmer periods when the barriers to transport are removed, icebergs can exit the fjords onto the shelf and still retain a sediment load.

Mafic-rich Tertiary and Quaternary flood basalts crop-out on either side of Denmark Strait (Larsen, 1983). On the Greenland side the outcrop extends from the south shore of Scoresby Sund southward to Kangerlussuaq Fjord; it also extends offshore (Larsen, 1983; Brooks, 1990). To the north of Scoresby Sund, the geology is complex (Henriksen, 2008) but the bedrock is dominated by igneous and metamorphic rocks, with some Paleozoic sandstones (red beds) (Pirrung et al., 2002) and carbonates. Offshore sediments are rich in quartz and kfeldspars, thus they present a clear mineralogical contrast with similar processes affecting the basalts of East Greenland and Iceland (Andrews et al., 2010).

\section{Sediment loads and transport}

A key question, and one that is difficult to answer in absolute terms, is the magnitude of the sediment load that is transported in the icebergs and sea ice, and which is thus available to melt-out and be deposited on the seafloor (Hebbein, 2000; Dethleff, 2005; Dethleff and Kuhlmann, 2009, 2010). In glacial marine environments there is another reworking and transport mechanism, which is the impact of large icebergs on the seafloor, and which causes sediment reworking and resuspension (Dowdeswell et al., 1994, 2010; Syvitski et al., 2001). The flux of water in the East Greenland Current through Fram Strait (EGC) is of the order of $3000-5000 \mathrm{~km}^{3} / \mathrm{yr}$ (Foldvik et al., 1988), compared with an annual iceberg flux north of Kangerlussuaq Trough of $\sim 100 \mathrm{~km}^{3}$ (Bigg, 1999) and a sea ice flux in the range of $\sim 700 \mathrm{~km}^{3} / \mathrm{yr}$ (Kwok, 2009). The magnitude of the iceberg sediment load along the East Greenland margin is essentially unknown, however, there are some critical observations that need to be considered. In fast-flowing tidewater ice streams the sediment is usually held within the lowermost 1-10 m (Dowdeswell, 1986), although, if there is a pronounced sill, considerable thickness of sediment can be added through the freezing on of super-cooled basal melt-water (Alley et al., 1997, 1998; Lawson et al., 1998). A key consideration is that along the E/NE Greenland margin, icebergs are restricted in moving out of the fjords and onto the shelf by the presence of land-fast sea ice and/or the sikkussuaq (a mélange of sea ice, bergy bits, and icebergs) (Syvitski et al., 1996; Reeh et al., 1999, 2001). Thus the icebergs suffer significant mass loss during their "enforced captivity, " hence most probably lose a considerable fraction of their sediment. An order of magnitude estimate of the sediment load in icebergs $\left(100 \mathrm{~km}^{3}\right.$ of ice calved (Bigg, 1999), average iceberg thickness of $200 \mathrm{~m}$ (Dowdeswell et al., 1992), hence $500 \mathrm{~km}^{2}$ area coverage, a $2 \mathrm{~m}$ sediment thickness) is $2600 \times 10{ }^{9} \mathrm{~kg}$, or a mass accumulation rate (MAR) $\sim 0.5 \mathrm{mg} / \mathrm{cm}^{2} / \mathrm{yr}$ if distributed evenly over the $500,000 \mathrm{~km}^{2}$ shelf of NE Greenland, north of $68^{\circ} \mathrm{N}$. Melting of the margin of the Greenland Ice Sheet below the Equilibrium Line produces ca $273 \mathrm{Gt}\left(\mathrm{km}^{3}\right)$ of melt-water per year (van den Broeke et al., 2009), probably < $1 / 4$ of this from NE Greenland. However, from a sediment transport viewpoint, the flux of sediment entrained in the melt-water plumes decreases exponentially away from the ice front (Andrews and Syvistki, 1994; Syvitski et al., 1996; Mugford and Dowdeswell, in press) with a half-distance transport length of $10^{\prime} \mathrm{s}$ of $\mathrm{km}$, thus resulting in massive deposition within the fjords (Smith and Andrews, 2000) but with relatively little impact on the mid- and outer shelf. 


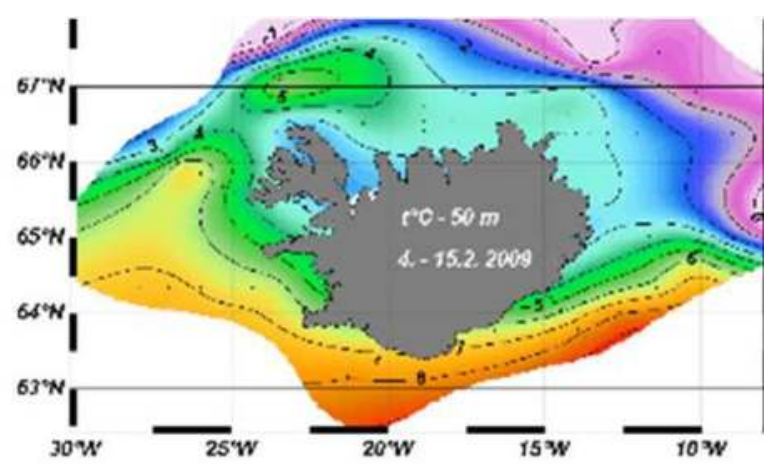

Fig. 2. Temperatures at $50 \mathrm{~m}$ water depth across the North Iceland Front (Belkin et al., 2009) (www.hafro.is)

The sediment load in sea ice exiting through Fram Strait (Fig. 1) has been estimated at ca 158 $x 10^{9} \mathrm{~kg}$ (Dethleff and Kuhlmann, 2010), thus a potentially smaller MAR $\left(\sim 0.03 \mathrm{mg} / \mathrm{cm}^{2} / \mathrm{yr}\right)$ than the crude estimate (above) for the iceberg sediment load. These estimates will vary spatially and temporally, thus a sediment trap in Fram Strait recorded a MAR of 0.29 $\mathrm{mg} / \mathrm{cm}^{2} / \mathrm{yr}$ from the melting of sea ice (Hebbein, 2000).

Sea ice, sediment, and driftwood are exported from the Arctic Ocean via the TransPolar Drift (Fig. 1) (Eggertsson, 1993; Dyke et al., 1997; Tremblay et al., 1997). Sediments in the sea ice "...contain on average more than 94\% silt and clay" (Dethleff and Kuhlmann, 2010), and the process of sediment entrainment in sea ice (Reimnitz et al., 1987; Darby, 2003; Darby et al., 2009; Dethleff and Kuhlmann, 2009) results in an enhancement of the fine-fractions relative to sediments on the sea floor. Dethleff and Kuhlmann (2010) were able to distinguish between eastern (Kara Sea) and and western (Laptev Sea) sources based on clay mineralogy. Similarily, Darby and Bischoff (1996) were able to distinguish sources based on the Fe-oxide compositon of grains in the $250-40 \mu \mathrm{m}$ fraction; Darby also identified grains from the Laptev and Kara seas in cores off N Iceland (Andrews et al., 2009b).

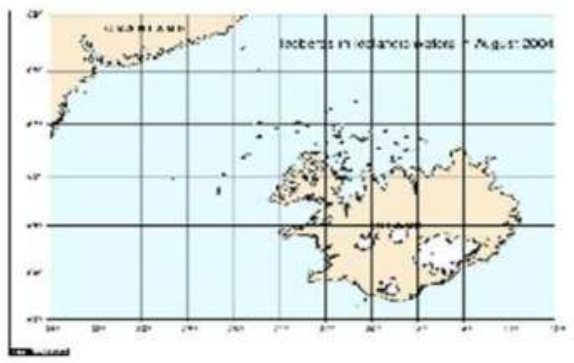

Fig. 3. Distribution of icebergs off NW and N Iceland in August 2004 (www.harfo.is)

Sediment transport via sea ice will of course end at the limit of sea ice. This is a spatially and temporally variable limit (Parkinson, 2000; Parkinson et al., 2001) with significantly expanded aerial extent during the Little Ice Age (Gray, 1881b; Koch, 1945; Wallevik and 
Sigurjonsson, 1998; Ogilvie and Jonsdottir, 2000; Divine and Dick, 2006) (Fig. 1). SW Iceland is predicted to be essentially "ice free" whereas NW/N Iceland have intermittent sea ice and icebergs (Figs. 1 and 3). However, there is, unfortunately, no record of iceberg numbers along the East Greenland margin, such as there is for the eastern Canadian margin off Newfoundland (Miller and Hotzel, 1984; Marko et al., 1994; Bigg, 1999). Icebergs are noted in recent observations on the Iceland shelf (Sigurdsson, 1969) (Fig. 3). The driftwood on Iceland beaches (Eggertsson, 1993) is brought on and in sea ice, and originates from the Russian mainland west of the Ural Mountains, thus firmly indicating long distant transport.

\section{Methods}

This chapter is based on published core data from areas of the Kara Sea (Stein et al., 2004) southward to $65^{\circ} \mathrm{N}$ off East Greenland (Fig. 1) (Andrews et al., 2010), and sites around Iceland (Andrews et al., 2009b) (Table 1). Estimates of the sediment accumulation rates (SAR) and mass accumulation rates (MAR) are based on published data and on the sediment properties of the two shelf areas (Andrews et al., 2002).

There are a variety of different approaches to obtaining qXRD weight $\%$ estimates ( $\mathrm{wt} \%)$ of non-clay and clay minerals (Kolla et al., 1979; Ward et al., 1999; Eberl, 2003; Moros et al., 2004). The method used in this chapter is described by Eberl (2003); it has been very successful (2nd and $3^{\text {rd }}$ place) in the International Reynolds Cup, in which "unknown" mixtures of minerals are sent to laboratories around the world for identification (McCarty, 2002). Briefly, $1 \mathrm{~g}$ of dry bulk sediment in the $<2 \mathrm{~mm}$ size range (i.e. sand, silt, and clay) is mixed with $0.111 \mathrm{~g}$ of $\mathrm{ZnO}$ and ground for 5 minutes in a McCrone mill. The samples are then dried, side packed in aluminum holders and loaded into a 40 -sample carousel on a D5000 Siemens X-ray diffraction instrument. The samples are run between $5^{\circ}$ and $65^{\circ} 2$-theta with a scan of $2 \mathrm{sec}$ every $0.02^{\circ}$ two-theta (100 minutes per sample). This results in 3000 counts per sample. The digital output is loaded into a $50 \mathrm{MB}$ Excel macro program called RockJock v6 (Eberl, 2003), which has 125 mineral standards. The XRD sample pattern is matched to an estimated XRD pattern based on the selection of minerals that experience indicates may be present. A graph is generated that shows major residual XRD peaks so that the mineral selection can be altered. In practice, for the down core analyses, a single selection is made of around 23 non-clay and 10 clay mineral species (Andrews and Eberl, 2007). A degree-of-fit (DOF) is iteratively calculated between the observed and expected patterns and a selection is finally arrived at after 5 iterations with no change in the $4^{\text {th }}$ decimal place. This usually takes 20-30 minutes on a regular PC. In glacial marine environments the focus has been on the non-clay mineralogy as this usually includes anywhere from 70-90 wt\% of the bulk sediment (Andrews and Eberl, 2007; Andrews et al., 2010).

An additional research step is undertaken using an unmixing algorithm "MinUnMix" (Eberl, 2004; Andrews et al., 2010) and the latest version, which is termed "SedUnMix" (Andrews and Eberl, subm.). This program uses linear algebra programming (using the "Solver" in Excel). The steps are illustrated in Table 2 with an abbreviated list of minerals (8) that are summed to $100 \%$. The objective is to consider how well the mineral composition from NW Iceland (Fig. 4) can be explained by contributions from 4 sources (Table 2A), Iceland, Kara Sea, Scoresby Sund, and Nansen Fjord (Geikie Plateau) (Figs. 1, 4, 5 and 6). Core JR51GC35 (Bendle and Rosell-Mele, 2007) (Fig. 5) is used. The program iteratively seeks to minimize the absolute differences between the target compositions (samples from. 


\begin{tabular}{|c|c|c|c|c|c|c|c|c|}
\hline Core Id & Long & Lat & \#1 & \#2 & \#3 & $\# 4$ & \#5 & \#6 \\
\hline MD99-2258 & -24.44 & 63.96 & 0.16 & 0.075 & 68 & 16.40 & & 0.30 \\
\hline HU93030-003I & -24.23 & 64.30 & 0.22 & 0.100 & 140 & & & NA \\
\hline MD99-2256 & -24.21 & 64.32 & & 0.030 & 24 & 7.90 & & 0.10 \\
\hline B997-343 & -24.49 & 64.78 & & 0.030 & 237 & NA & & NA \\
\hline B997-330 & -21.08 & 65.87 & & 0.060 & 47 & 1.40 & & 0.50 \\
\hline JM96-1216 & -30.63 & 65.96 & & 0.026 & 21 & 5.50 & 4.00 & 9.40 \\
\hline BS1191--K18B & -30.63 & 65.96 & & 0.006 & 5 & 9.90 & 9.80 & 5.60 \\
\hline MD99-2266 & -23.27 & 66.23 & & 0.135 & 106 & 17.70 & & 0.00 \\
\hline MD99-2269 & -20.86 & 66.64 & & 0.250 & 197 & 9.20 & & 3.60 \\
\hline MD99-2263 & -24.20 & 66.68 & 0.08 & 0.040 & 28 & 28.60 & & 1.20 \\
\hline MD99-2264 & -24.20 & 66.68 & & 0.021 & 16 & 28.60 & & 0.90 \\
\hline B997-315 & -24.33 & 66.74 & & 0.008 & & 26.90 & & 1.00 \\
\hline JR51GC-35 & -17.96 & 67.00 & & 0.040 & 32 & 3.00 & & 1.90 \\
\hline MD99-2322 & -30.83 & 67.14 & & 0.117 & 95 & 3.20 & & 9.20 \\
\hline HU93030-019B & -30.82 & 67.15 & 0.20 & & 90 & 6.10 & 0.80 & 6.60 \\
\hline JM96-1207 & -29.35 & 68.10 & & 0.015 & 12 & 0.80 & & 7.70 \\
\hline MD99-2317 & -27.86 & 68.10 & & 0.054 & 44 & 0.00 & & 3.70 \\
\hline HU93030-023 & -31.88 & 68.14 & 0.42 & & 430 & NA & & NA \\
\hline JM96-1212 & -31.36 & 68.16 & 0.31 & & 250 & NA & & NA \\
\hline JM96-1210 & -29.60 & 68.18 & 0.22 & 0.125 & 170 & 0.00 & & 6.00 \\
\hline BS1191-K8 & -30.09 & 68.26 & & 0.372 & 305 & 0.30 & NA & 10.50 \\
\hline JM96-1209 & -29.80 & 68.30 & 1.36 & & 1010 & NA & & NA \\
\hline
\end{tabular}

$1=\mathrm{SAR} \mathrm{cm} / \mathrm{yr} 210 \mathrm{~PB}$

$2=\mathrm{SAR} \mathrm{cm} / \mathrm{yr} 14 \mathrm{C}$

$3=\mathrm{mg} / \mathrm{cm} 2 / \mathrm{yr}$

$4=w t \%$ calcite

$5=\mathrm{wt} \%$ bio silica

$6=\mathrm{wt} \%$ qrtz

Table 1. Core data and locations (Fig. 5). Not all core identifications are shown.

JR51GC35) and calculated compositions (Table 2B) based on fractions of contributions from the four sources (Table $2 \mathrm{C}$ ). Errors on source contributions ( \pm one standard deviation) are computed from randonly generated iterations (Table 2A)---in this example I show the results for 2 samples dated $\sim 620$ andf $1550 \mathrm{yr}$ BP based on 10 iterations (Table 2C). The data are not constrained to sum to $100 \%$ but usually range within $\pm 20 \%$ of that total. The results (Table 2C) indicate a dominance of local Icelandic-sourced sediments but with contributions from East Greenland 
Sources

$1=$ Iceland

$2=$ Kara Sea

$3=$ Scoresby Sund

$4=$ Nansen Fjord

A Random sample 1 to 5

Quartz

intermediate Microcline feldspar

Anorthoclase feldspar

Bytownite feldspar

Pyroxene

Saponite

Ferruginous smectite

Fe-Chlorite

Random sample 1 to 5

Quartz

intermediate Microcline feldspar

Anorthoclase feldspar

Bytownite feldspar

Pyroxene

Saponite

Ferruginous smectite

Fe-Chlorite

k iterations 1 to 200

B Minerals present

Quartz

intermediate Microcline feldspar

Anorthoclase feldspar

Bytownite feldspar

Pyroxene (diopside)

Saponite

Ferruginous smectite

Fe-Chlorite (Tusc)

Mean absolute difference

\section{Minerals present}

Quartz

intermediate Microcline feldspar

Anorthoclase feldspar

Bytownite feldspar

Pyroxene (diopside)

Saponite
1.3

0.0

0.0

37.4

10.0

12.2

28.5

0.0

11.8

1.2

1.1

0.2

36.7

8.1

13.9

27.5

0.0

12.6

Target $620 \mathrm{yr}$

1.9

1.5

37.1

10.3

14.7

19.1

0.7

14.7

Target $1550 \mathrm{yr}$

2.3

0.3

37.9

10.6

17.5

18.1
2.1

28.8

9.0

6.1

0.3

1.9

18.8

13.8

21.1

2.5

34.1

7.4

14.4

8.7

7.9

8.4

9.1

10.0
3.4

4.1

$10.6 \quad 8.6$

$3.2 \quad 7.4$

$28.4 \quad 14.1$

$\begin{array}{ll}6.6 & 13.8\end{array}$

$15.3 \quad 19.8$

$19.5 \quad 20.6$

$9.8 \quad 6.6$

$6.7 \quad 9.1$

$3.4 \quad 4.5$

$10.0 \quad 11.6$

$\begin{array}{ll}7.0 & 3.0\end{array}$

$29.0 \quad 17.6$

$6.4 \quad 10.5$

$12.9 \quad 16.6$

$15.2 \quad 24.4$

$9.9 \quad 5.7$

$9.7 \quad 10.5$

Calculated Difference

$-0.2$

0.5

2.6

0.0

1.0

$-6.8$

$-0.8$

2.9

1.8

Calculated Meas-Calc

$2.0 \quad 0.3$

$0.7 \quad-0.4$

$35.0 \quad 2.8$

$10.6 \quad 0.0$

$\begin{array}{lll}17.5 & 14.4 & 3.2\end{array}$

$26.4-8.3$ 
Ferruginous smectite

Fe-Chlorite (Tusc)

Mean absolute difference

C

Mixed sample JR51GC35

620

1550

Mixed sample JR51GC35
0.8

12.5

1.1

12.4
$-0.2$

0.1

1.9

$\begin{array}{rrrrr} & 3 & \pm & 4 & \pm \\ 620 & 0.07 & 0.09 & 0.08 & 0.09 \\ 1550 & 0.05 & 0.08 & 0.13 & 0.08\end{array}$

All ages in this chapter are calibrated yr BP (Stuiver et al., 1998) but are simply noted as yr BP.

Table 2. Explanation of the steps in the mineral unmixing program SedUnMix

\section{Research design}

A glaciated margin, such as E/NE Greenland (Fig. 1) consists of a series of point sources (ice streams and tidewater glaciers), which contribute sediment along fjords and into the main north- $\rightarrow$ south flow of the East Greenland Current (Fig. 4). Another potential sediment source to the E Greenland and Iceland margins are sediments entrained in sea ice and exported through Fram Strait (Figs. 1 and 4). The water, sea ice, and iceberg transport along the NE/E Greenland shelf are variable, with the former two being primarily forced by changes in sea-level pressure associated with the Arctic Oscillation (Thompson and Wallace, 1998; Schmith and Hanssen, 2003; Rogers et al., 2005).

Based on our Experimental design (Fig. 4) the chapter will examine the following hypotheses:

Hypothesis 1: The sediments deposited on the NW Iceland shelf and central East Greenland shelf are largely derived from sea ice entrained sediments originating on the shallow shelves of the Arctic Ocean.

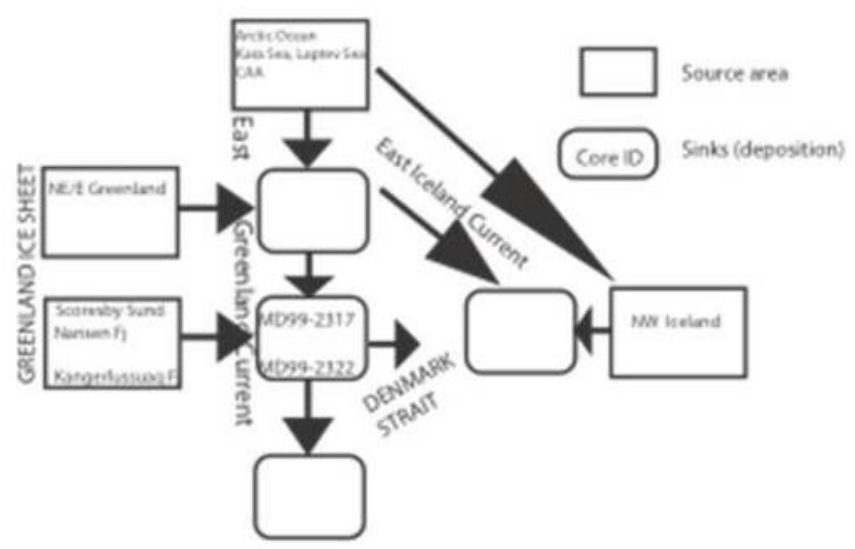

Fig. 4. Research desing in terms of sediment transport from the Artic Ocean (sea ice) and East Greenland (icebergs) to depositional stes off East Greenland and N Iceland 
Alternate Hypothesis: The sediments deposited on the NW Iceland shelf and central East Greenland shelf are largely derived from NE/E Greenland icebergs and melt-water.

In order to investigate these hypotheses there is a need to determine: 1) the mass accumulation rates in the areas of interest-the deposition areas, 2) the mineralogy of the bulk sediment in both the source areas and the areas of deposition (sinks), and 3) estimate the relative sediment source contributions in the areas of deposition. In order to undertake the project I will use results from seafloor surface sediments from the Kara Sea, NE/E Greenland, and Iceland, and down-core data from cores MD99-2269, MD99-2317, and JR51GC35 (Fig. 5) (Andrews et al., 2009b, 2010). I used the qXRD method (Eberl, 2003) to identify 22 non-clay and 9 clay minerals. However, several species occurred infrequently or with low $(<1 \%)$ wt $\%$ and the number of minerals was reduced to 20 for analysis with "SedUnMix".

\section{Mass accumulation rates}

Sediment accumulation rates (SAR) and mass accumulation rates (MAR) provide initial guidelines on sediment transport. Mass accumulation rates $\left(\mathrm{mg} / \mathrm{cm}^{2} / \mathrm{yr}\right)$ have been estimated from a combination of sources, including ${ }^{210} \mathrm{~Pb}$ measurements, and radiocarbon dated SAR (Smith et al., 2002; Andrews et al., 2009a; Axford et al., in press). In the latter case the measurements have been converted to mass accumulation rates using average dry densities (Andrews et al., 2002). The values for MAR range from 1000 to $5 \mathrm{mg} / \mathrm{cm}^{2} / \mathrm{yr}$ (Table 1). The estimates across Denmark Strait (Fig. 5) show the expected pattern of high inshore values and decreasing toward the shelf break. An exception is the high MAR ( 200) from MD99-2269 off N Iceland (Stoner et al., 2007). MAR decreases non-linearly from the East Greenland coast to the shelf break, such that the MAR has decreased from 1000 to 100 $\mathrm{mg} / \mathrm{cm}^{2} / \mathrm{yr}$ in $150 \mathrm{~km}$ (Andrews et al., 1997; Smith et al., 2002). At the moment there are no reliable MARs for sites in and north of Scoresby Sund.

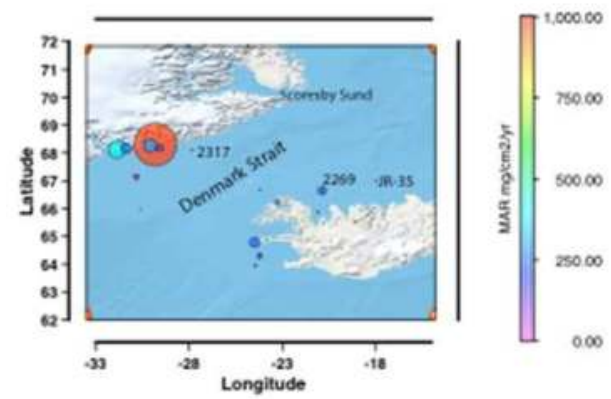

Fig. 5. Late Holocene mass accumulation rates across Denmark Strait $\left(\mathrm{mg} / \mathrm{cm}^{2} / \mathrm{yr}\right)$ based on ${ }^{210} \mathrm{~Pb}$ and ${ }^{14} \mathrm{C}$ estimates. Core locations are shown for sites (Table 1)illustrated further in Figures 8 and 10 .

The MAR estimates for Iceland are biased toward larger values because of the export by wind and water of volcanic glass; roughly $1 / 2$ of the sediment is estimated to be derived from Holocene volcanic activity (Andrews, 2007). In marine situations, MARs consist of a transported mineral component and an in situ biological component formed by the 
production of biogenic calcite (foraminifera and coccoliths), aragonite, and silica (diatoms). As part of the qXRD analyses all three of these components are determined (Table 1). Apart from sites off NW Iceland, which are enriched in calcite due to reworking of shelf sediments, the biogenic $w t \%$ estimates usually total $<6-w t \%$. The impact of the intermediate Irminger Current waters in the Kangerlussuaq Trough (Jennings et al., 2011) are readily apparent from the values of calcite $w t \%$ versus very low values at sites to the north (Table 1).

\section{Mineralogy of sources and sinks}

Figure 6 illustrates the mineral compositions of source areas (Fig. 4), which provide sediments for transport to distal sites either in sea ice or icebergs. The 11 of the 20 minerals used are summed to $100 \%$ for the pie diagrams.

Kara Sea to N Iceland: A potential source for sea ice sediments and driftwood off Iceland is the area west of the Ural Mountains and especially the shallow $(<50 \mathrm{~m} \mathrm{wd}$ ) shelf of the Kara Sea (Eggertsson, 1993). Sand, silt, and clay separates were obtained from surface samples from ther Kara Sea (Stein et al., 2004) and were processed for qXRD. I focus on the combined silt and clay mineralogy as these fractions are enhanced in sea ice sediments due to the entrainment process (Dethleff, 2005). The silt fraction has high values in quartz, various feldspars and about $15-w t \%$ of smectites. Pyroxene is present but with a low wt $\%$. However, the clay fraction consists of about $10 \%$ quartz and nearly 70 -wt $\%$ are smectites (saponite and ferruginous smectite) due to weathering of the $2 \times 10 \mathrm{~km}^{2}$ outcrop of the $250 \mathrm{Ma}$ old Siberian Traps. Kaolinite (not included) was $\leq 5-w t \%$ in the clay fraction.

Given the sea ice limits around Iceland, the trajectory of the TransPolar Drift and East Iceland Current (Figs. 1 \& 2), and the location of the marine North Iceland Front (Fig. 5), then a sea ice sediment transport from the Kara Sea, and deposition to the N Iceland margin is probable (Moros et al., 2006). In terms of mineral tracers for a Kara Sea sediment source (Fig. 6), it has higher wt\% of quartz, saponite, ferruginous smectite, and Fe-chlorite than samples from East Greenland or Iceland. Quartz and k-feldspars do not occur in any significant amounts within the bedrock of Iceland (Eiriksson et al., 2000) and they have, therefore, been used as an index of ice-rafting debris (IRD) (Eiriksson et al., 2000; Moros et al., 2006; Andrews, 2009; Andrews et al., 2009b) (e.g. Fig. 6, and Table 2A Iceland samples). Core MD99-2269 is a well-dated 25-m long core off N Iceland (Stoner et al., 2007) (Fig. 7A), and which has been studied with a large number of proxies (Andrews et al., 2003; Giraudeau et al., 2004; Moros et al., 2006; Kristjansdottir et al., 2007). Figure 7A shows a plot of the quartz wt\% (Moros et al., 2006) versus the silt and clay fractions in this core---notice silt plus clay total between 86 and $98 \%$, with a persistent increase in this fraction over the last $8000 \mathrm{yr}$ BP. Over the last $4000 \mathrm{yr}$ BP the $<63 \mu \mathrm{m}$ fraction and quartz wt $\%$ track each other, but there are significant discrepancies in the association between 7000 and 12,000 $\mathrm{yr}$ BP.

Because the last 4000-6000 yr BP has seen the regrowth of glaciers and re-expansion of the Greenland Ice Sheet and Iceland glaciers (Geirsdottir et al., 2009; Kelly and Lowell, 2009) it is surprising that N Iceland and E Greenland sediment (Andrews et al., 2010) show a pervasive fining-upward signal. Given the grain-size selectivity of sea ice sediment entrainment (Dethleff and Kuhlmann, 2009, 2010) the fining-upward sediments may reflect an increase in sediment transport from the Arctic Ocean. 


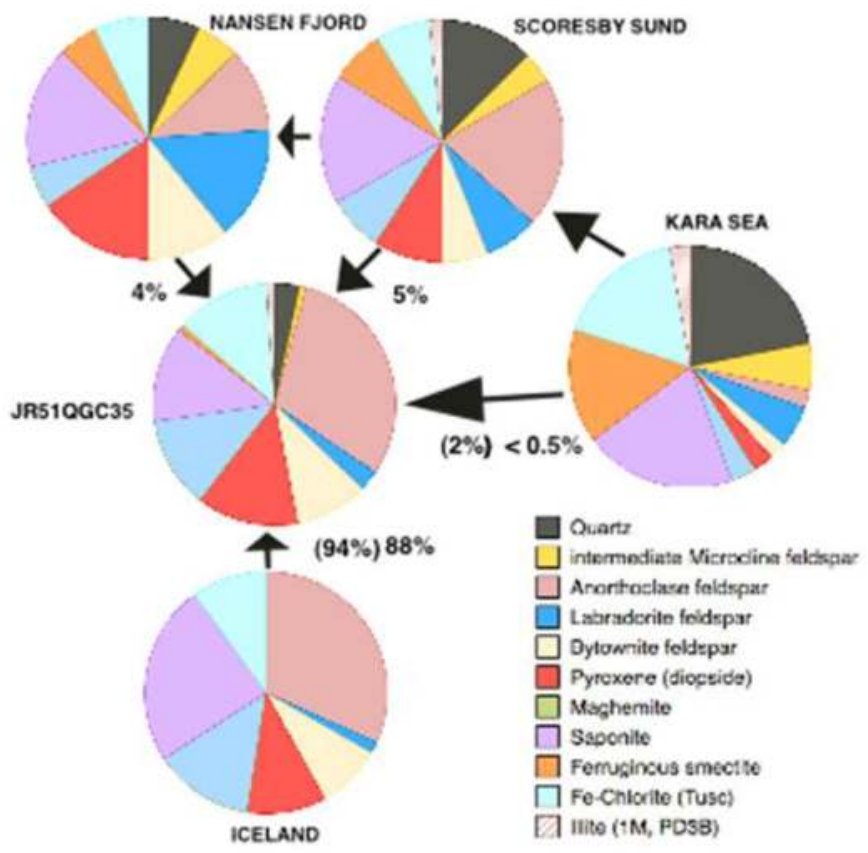

Fig. 6. Potential transport diagram for sediments at core site JR51GC35 (Fig. 5), N Iceland. For clarity only the most plentiful species out of 20 total are shown in the pie diagrams. Figures refer to the average contributoin from the sources to JR51GC35, those in brackets relate to the two end member solution.

To test the hypothesis that Iceland offshore sediments retain an imprint of sediment transport from the Arctic Ocdean via sea ice, I examine the mixing of sediments on the $\mathrm{N}$ Iceland outer shelf on core JR51- GC35 (Bendle and Rosell-Mele, 2007) (Tables 1 and 2, Fig. 5 ) between two sources; the first being local inner shelf Iceland sediments (represented by MD99-2258, (Axford et al., in press), Table 1) and the other being Kara Sea surface sediments (Fig. 6). The average sampling interval for the qXRD data is $85 \mathrm{yr}$. I use data from JR51GC35 because the qXRD results on MD99-2269 only reported quartz, plagioclase, and calcite $w t \% s$ (Moros et al., 2006). However, the quartz wt $\%$ data from JR51-GC35 closely parallels the MD99-2269 data (Andrews, 2009) (Fig. 7B). Twenty non-clay and clay mineral species were identified by qXRD and were processed using the linear progamming software in the Excel "Solver," and using the program SedUnMix (Table 2) (Eberl, 2004; Andrews and Eberl, subm.). The two sources were each represented by 5 samples. The average absolute difference in mineralogy was $3.1 \mathrm{wt} \%$ on 20 species (e.g. Table 2B). The estimated contribution from the Kara Sea only averaged $2 \%$ (Fig. 6) but shows a systematic increase over the last $6000 \mathrm{yr}$ BP (Fig. 7B), which roughly parallels the change in quartz wt\% (note that quartz is only $1 / 20$ of the minerals in the SedUnMix calculation). However, it is known that icebergs drift into NW/N Iceland waters (Fig. 3) thus E/N Greenland could also be a source of the felsic minerals in JR51GC35 (see below). 


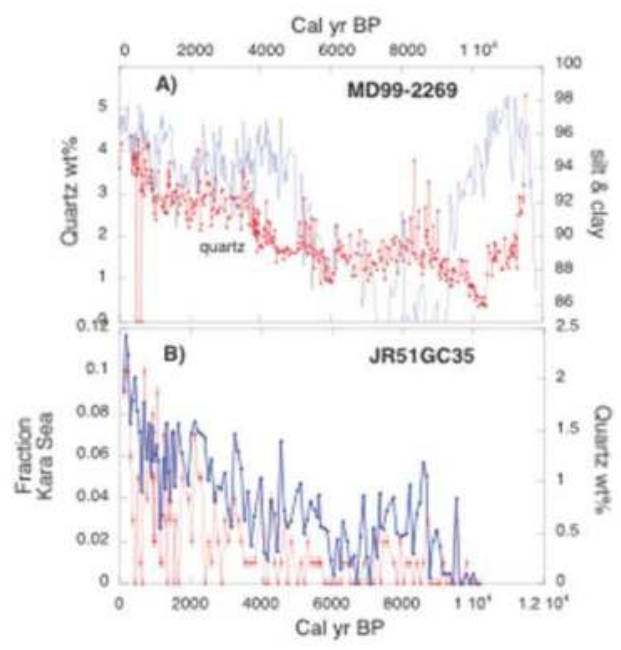

Fig. 7. A) Quartz wt $\%$ and the fraction of sediment $<63 \mu \mathrm{m}$ (slit and clay) in MD99-2269 off $\mathrm{N}$ Iceland. B) Quarz wt\% (blue) at JR51-GC35 and the estimated fraction of sediment contributed from the Kara Sea (red) comparated with a local N Iceland composition (see Fig. 6.) with \pm standard error of the estimate.

NE to E Greenland: The TransPolar Drift exports sea ice sediments from the Arctic Ocean along the NW/E Greenland margin, with sediment also being contributed from local glaciers and ice streams (Fig. 4) (Evans et al., 2002). If sea ice were the pervasive sediment transport medium then the influence of the local glacier sources should be small. In particular, as sea ice traverses along the Tertiary basalt outcrop from the south shore of Scoresby Sund to Kangerlussuaq Fjord (Fig. 1) we would expect only small changes in sediment composition. However, Andrews et al. (2010) showed a major shift in mineral composition across this northern boundary. Earlier, Pirrung et al. (2002) showed a boundary in mass magnetic susceptibility extending seaward from Scoresby Sund with high values along the Tertiary basalt coastline. U-channel rock magnetic measurements on cores south of Scoresby Sund showed a gradual southward decrease in values, which was associated with a decrease in maghemite and in increase in felsic minerals (Andrews and Hardardottir, 2009). A similar abrupt break is present in the qXRD data (Fig. 8A \& B), where an abrupt change in mineralogy occurs north and south of Scoresby Sund from felsic-rich to mafic-rich sediments. These results strongly suggest that the seaward transport of glacially derived, mafic-rich sediments from the early Tertiary volcanic outcrop overwhelms the southward transport of felsic minerals from NE Greenland and the Arctic Ocean. However, single grains in the 250-40 $\mu \mathrm{m}$ range can still be used for identification (Fe-oxide composition) of source areas around the margin of the Arctic Ocean (Darby, 2003; Darby and Bischof, 2004; Andrews et al., 2009b).

2.3 Denmark Strait: Figure 9a \& B shows scaled weight\% values of quartz and pyroxene for surface samples from Scoresby Sund south and across to Iceland. These data extend the analysis of surface samples from NE Greenland (Fig. 8) and confirm the sharp boundary in 
sediment mineralogy associated with the Tertiary outcrop of the Geikie Plateau and the younger basalts of Iceland. Very low quartz weight \% values are found in Grivel Basin (GB, Fig. 9A) and values $\leq 1 \%$ occur off NW and SW Iceland (Axford et al., in press). The quartz $\mathrm{wt} \%$ values suggest two distinct transport paths for quartz (Fig. 9A) with low values characterizing the intervening area of the Denmark Strait area. The variations in quartz wt $\%$ in MD99-2269 and JR51-GC35 (Fig. 7) are associated with the transport of IRD in sea ice (possibly some icebergs, Fig. 3) in the East Greenland/East Iceland Current and deposition via melting as the polar waters reach the North Iceland Front (Fig. 2). The western quartz transport path (Fig. 9A) is directed from Kangerlussuaq Fjord and the large ice stream that calves in that fjord (Dwyer, 1993, 1995; Syvitski et al., 1996; Howat et al., 2008; Mugford and Dowdeswell, 2010). Use of an earlier version of SedUnMix on MD99-2322 from Kangerlussuaq Trough suggested that the contributions of sediment from the fjord (more felsic in nature) had steadily increased over the last 5000 cal yr BP (Andrews et al., 2010). Direct evidence for west to east transport across Denmark Strait during earlier times is seen in the early Tertiary ages of basaltic clasts in sediments off NW Iceland (Principato, 2003).
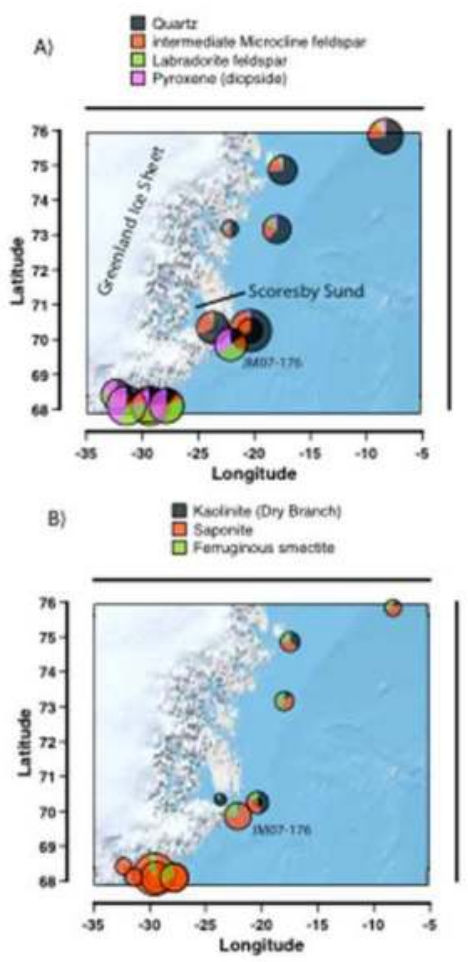

Fig. 8. A) Scaled pie diagrams to the sum of the four non-clay minerals on surface samples along the NE/E Greenland margin between $68^{\circ}$ and $76^{\circ} \mathrm{N}$. JM07-176 at $22.131^{\circ} \mathrm{W}$ and $69.859^{\circ} \mathrm{N}$, just south of Scoresby Sund marks the break from felsic-rich to mafic-rich sediments. B) As for $8 \mathrm{~A}$. but showing $w \mathrm{t} \%$ of kaolinite, saponite and Fe-smectite 
In another run of SedUnMix on the JR51GC35 data, two additional source areas were added, namely Scoresby Sund and inner shelf/fjord sediments off the Geikie Plateau (Figs. 2 and 6). The results indicated that the dominant source is still the Iceland mainland (Fig. 5) and $\sim 88 \%$ of the sediment on average is associated with this transport path (Fig. 6). In this $2^{\text {nd }}$ run, SedUnMix assigns some $8 \%$ of the sediment in JR51GC35 to transport from across Denmark Strait and only $<0.5 \%$ is associated with the Kara Sea. The Kara Sea contributions only commenced during the last $4000 \mathrm{yr}$ BP. Sediments attributed to the two East Greenland sources both show a steady increase over the Holocene. The comparison between the 2 or 4 source areas (Fig. 6) highlights a common problem in attempts to quantify sediment transport paths if the tracer(s) are not unique and have attributes in common (Grousset et al., 2000; Farmer et al., 2003).
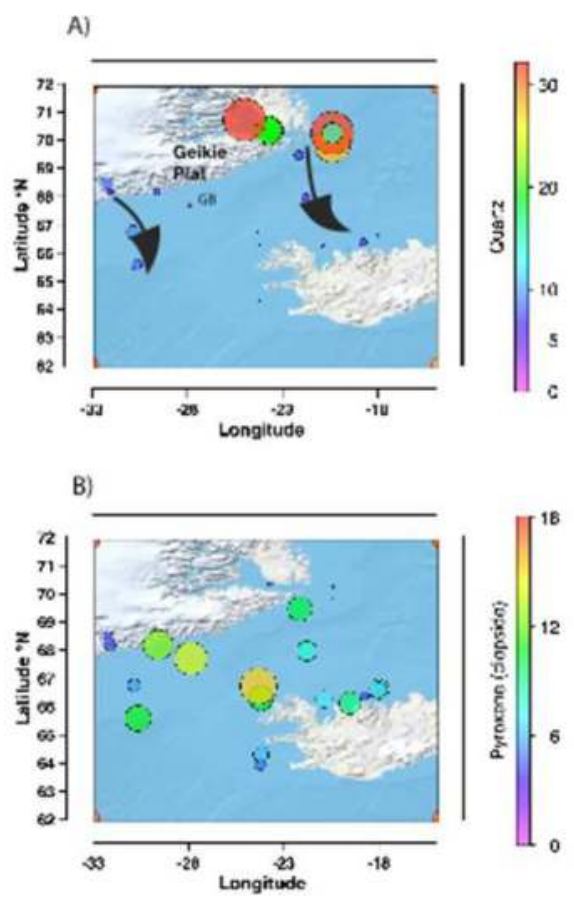

Fig. 9. Bubble plot of the weight $\%$ of A) Quartz and B) Pyroxene wt $\%$ from sites across Denmark Strait. Notice the sharp change in values along the southern edge of Scoresby Sund. See text for discussion of the arrows on A.

SedUnMix was then used to estimate the contribution from various sources to MD99-2317, a well-dated core in the Grivel Basin (GB, Fig. 9) with a sampling interval averaging 90 yr/sample---the core does not include the last $2000 \mathrm{yr}$ BP or so (Jennings et al., 2002; Andrews et al., 2010). Potential sources of sediment include the Kara Sea (and other shallow Arctic Ocean shelves (Fig. 6)), Scoresby Sund, and local ice caps and glaciers on the Geikie Plateau - the latter is represented by sediments from core JM96-1210 in Nansen Fjord (Jennings and Weiner, 1996). The sediments from Nansen Fjord contain small amounts of quartz derived from erosion of the underlying Precambrian basement rocks (Brooks, 1990). I 
thus include as a "pure" basaltic end member sediments from SW Iceland (Axford et al., in press). The average absolute difference on target minus the calculated mineral weight $\% \mathrm{~s}$ averages $2.1 \pm 0.43 \mathrm{wt} \%$ (e.g. Table 2B). The down core results (Fig. 10) indicate a dominance of transport seaward from the adjacent Geikie Plateau, as represented by the sediments from Nansen Fjord (91.9\% of the total). The percentage of sediment estimated to have been transported from the Kara Sea in sea ice is only $0.27 \%$, and the more felsic-rich contribution from Scoresby Sund (Fig. 9A) is 1.3\%. A pure basaltic contribution is estimated at $6.5 \%$. The contributions from the 4 sources are not randomly distributed during the Holocene (Fig. 10). Of particular note are the sharp peaks in sediments attributed to a Kara Sea source (Fig. 10A). Overall the analysis of the sediment composition indicates a steady increase in transport and deposition from the adjacent glaciated plateau whereas the contributions from felsic sources in Scoresby Sund have declined to zero by $4000 \mathrm{yr}$ ago (Fig. 10B). The apparent periodicity in the sediment input from Nansen Fjord (Fig. 10B) was tested using the multitaper method (MTM) (Mann and Lees, 1996; Ghil et al., 2002) on residual detrended (linear) data, integrated at $100 \mathrm{yr}$ intervals (Paillard et al., 1996). The results indicated two dominant periodicities at 910 (90\% CI) and $350 \mathrm{yr}$ (95\% CI) (Fig. 10C). The $350 \mathrm{yr}$ periodicity has been identified in several paleoclimate records and associated with solar variability (Clemens, 2005).

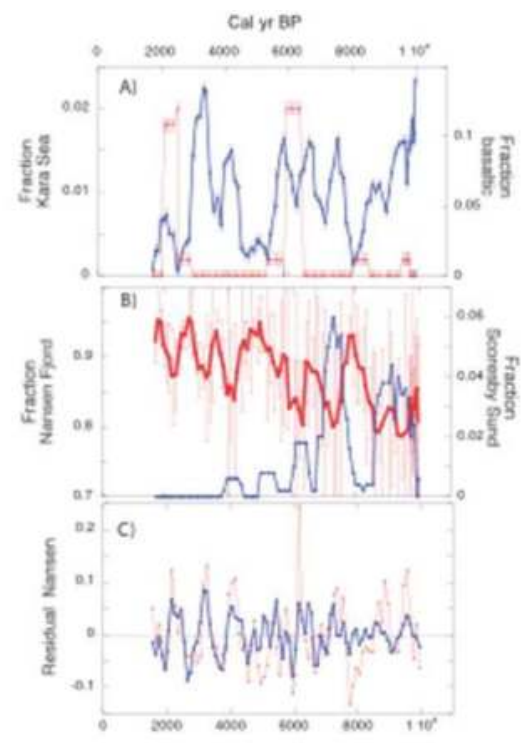

Fig. 10. Estimates of the sediment composition of MD99-2317 from Grivel Basin (GB, Fig. 9). Estimates based on the SedUnMix program (Eberl, 2004: Andrews and Eberl, subm.) and are 5-piont moving averages. A) Fractions of sediment from Kara Sea (red) or from basalt (blue)...error bars are \pm one standard error. B) Fraction of sediment from Nansen Fjord (red) and Scoresby Sund (blue). The error bars of the Nansen Fjord fractions are \pm one standard deviation based on 10 iterations of 4 end members with 5 samples each. C) Residuals from a linear trend of the fraction of Nansen Fjord sediments in MD99-2317 (red), versus the reconstructed time-series using the 350 and $910 \mathrm{yr}$ periodicities. 
A similar analysis was performed on the linear detrended residuals from the combined E Greenland contributions to JR51GC35. MTM analysis of those data indicated two weak periodicities $(90 \% \mathrm{CI})$ of 445 and $263 \mathrm{yr}$, the latter often linked to solar variability (Clemens, 2005). A comparison of the residual East Greenland fractions from JR51GC35 and MD992317 (Fig. 11) suggests several common intervals of enhanced sediment transport with some of the largest residuals occurring between 6000 and $7000 \mathrm{yr}$ BP.

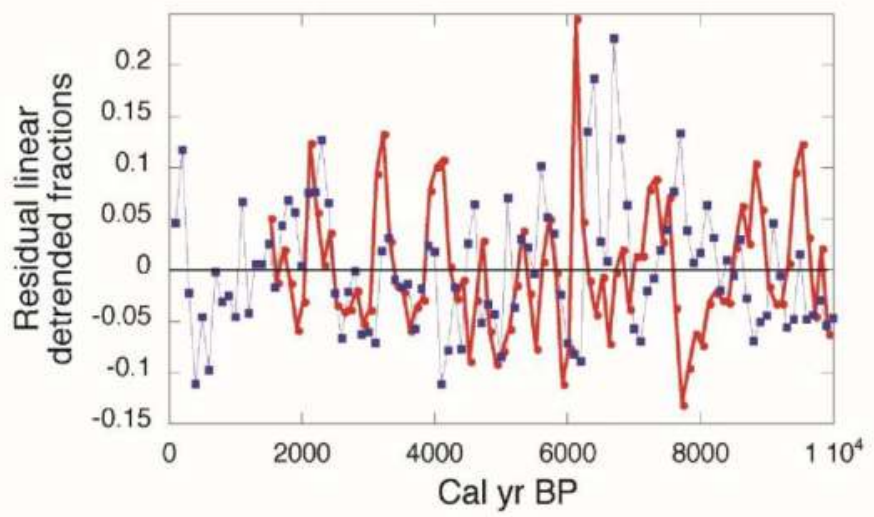

Fig. 11. Residuals from linear detrended data of the fraction of sediment contributed from Nansen Fjord to MD99-2317 (red) and from East Greenland sources (Fig. 6) to JR51GC35, N Iceland (blue).

\section{Conclusions}

Sediment transported by either sea ice or icebergs, i.e. ice-rafted, has the ability to be moved considerable distances from source areas. Thus potentially they provide key indicators of large-scale changes in either the distribution of sea ice or icebergs. The most dramatic examples are the so-called Heinrich events, which are a dramatic feature of the North Atlantic marine sediment archives during the last glaciation, and are recognized largely by their detrital carbonate content (Heinrich, 1988; Andrews and Tedesco, 1992; Bond et al., 1992). During the last 12,000 yr BP the changes in sediment transport from the Arctic Ocean and NE/E Greenland margin have been subtler, but this chapter demonstrates that quantitative X-ray diffraction analysis of marine sediments can be used to untangle changes in sediment sources and transport pathways (Figs. 4 to 10). Thus, as noted by Moros et al. (2004), quantitative mineral identification is an extremely powerful tool in establishing the connections between sediment sources $\rightarrow$ transportation $\rightarrow$ deposition.

Initially two hypotheses were proposed; the first stressed the importance of the Arctic Ocean sea ice as a sediment source, whereas the alternative thesis was that the bulk of the sediment was supplied from NE/E Greenland. The latter is more strongly supported by the data. Analysis of both the surface sediments (Figs. 8 and 9) and the down-core sediment composition (Fig. 10) indicate that the mineralogy immediately south of Scoresby Sund shifts abruptly from being felsic- to mafic-rich with $<2 \%$ of the sediment being attributed to sources from the Kara Sea or Scoresby Sund. These data demonstrate that glacial erosion of the basalt is overwhelming any contribution from sediments entrained in the East 
Greenland Current from sources north of $70^{\circ} \mathrm{N}$. On the east side of Denmark Strait, the north coast of Iceland (Fig. 5, JR51GC35) may record sediment input from the Kara Sea (Fig. 7B) while the relationship between the silt \% and quartz $\%$ over the last few thousand years (Fig. 7A) may reflect the export of silt-rich sediments from the shallow Arctic Ocean shelves via sea ice. However, further analysis suggested that the major external sediment sources to JR51GC35 were more closely affiliated mineralogically to sources across Denmark Strait than the Kara Sea.

\section{Acknowledgements}

I wish to thank the National Science Foundation for funding much of the research that led to this chapter, in particular grants ATM-0502515, OPP-070713755, and OCE-0823535. I also wish to thank INSTAAR and the Department of Geological Sciencese of Colorado at Boulder, for their support over 4 decades. I wish to thank Dennis Eberl from the USGS in Boulder who has worked with me (see references) on several projects and shared his experience and knowledge. Work on sample preparation has been assisted by assistance from Casey Coleman and the maintenance of the INSTAAR XRD unit has been in the capable hands of Wendy Roth. Drs R. Stein, H. Grobe, and J. Evans kindly provided samples from the Kara Sea and NE Greenland.

\section{References}

Alley, R. B., Cuffey, K. M., Evenson, E. B., Lawson, D. E., and Strasser, J. C., 1997: How glaciers entrain and trasnport basal sediment: Physical constraints. Quaternary Science Review, 16: 1017-1038.

Alley, R. B., Lawson, D. E., Evenson, E. B., Strasser, J. C., and Larson, G. J., 1998: Glaciohydraulic supercooling: a freeze-on mechanism to create stratified, debrisrich basal ice: II. Theory. Journal of Glaciology, 144: 563-569.

Andrews, J. T. and Tedesco, K., 1992: Detrital carbonate-rich sediments, northwestern Labrador Sea: Implications for ice-sheet dynamics and iceberg rafting (Heinrich) events in the North Atlantic. Geology, 20: 1087-1090.

Andrews, J. T. and Syvistki, J. P. M., 1994: Sediment fluxes along high latitude continental margins (NE Canada and E. Greenland). In Hay, W. (ed.), Material fluxes on the surface of the Earth. Washington, D.C.: National Academy Press, 99-115.

Andrews, J. T., Smith, L. M., Preston, R., Cooper, T., and Jennings, A. E., 1997: Spatial and temporal patterns of iceberg rafting (IRD) along the East Greenland margin, ca. 68 $\mathrm{N}$, over the last 14 cal.ka. Journal of Quaternary Science, 12: 1-13.

Andrews, J. T., 1998: Abrupt changes (Heinrich events) in late Quaternary North Atlantic marine envrionments: a history and review of data and concepts. Journal of Quaternary Science, 13: 3-16.

Andrews, J. T., Kihl, R., Kristjánsdóttir, G. B., Smith, L. M., Helgadóttir, G., Geirsdóttir, Á., and Jennings, A. E., 2002: Holocene sediment properties of the East Greenland and Iceland continental shelves bordering Denmark Strait $\left(64^{\circ}-68^{\circ} \mathrm{N}\right)$, North Atlantic. Sedimentology, 49: 5-24.

Andrews, J. T., Hardardottir, J., Stoner, J. S., Mann, M. E., Kristjansdottir, G. B., and Koc, N., 2003: Decadal to millennial-scale periodicities in North Iceland shelf sediments 
over the last 12,000 cal yrs: long-term North Atlantic oceanographic variability and Solar forcing. Earth and Planetary Science Letters, 210: 453-465.

Andrews, J. T. and Eberl, D. D., 2007: Quantitative mineralogy of surface sediments on the Iceland shelf, and application to down-core studies of Holocene ice-rafted sediments. Journal of Sedimentary Research, 77: 469-479.

Andrews, J. T., 2007: Holocene denudation of Iceland as determined from accumulation of sediments on the continental margin. Boreas, 36: 240-252.

Andrews, J. T., 2009: Seeking a Holocene drift ice proxy: non-clay mineral variations from the SW to N-central Iceland shelf: trends, regime shifts, and periodicities. Journal of Quaternary Science, 24: 664-676.

Andrews, J. T., Belt, S. T., Olafsdottir, S., Masse, G., and Vare, L., 2009a: Sea ice and marine climate variability for NW Iceland/Denmark Strait over the last $2000 \mathrm{cal}$. yr BP. The Holocene, 19: 775-784.

Andrews, J. T., Darby, D. A., Eberl, D. D., Jennings, A. E., Moros, M., and Ogilvie, A., 2009b: A robust multi-site Holocene history of drift ice off northern Iceland: Implications for North Atlantic climate. The Holocene, 19: 71-78.

Andrews, J. T. and Hardardottir, J., 2009: A comparison of Holocene sediment- and paleomagnetic characteristics from the margins of Iceland and East Greenland. Jokull, 59: 51-66.

Andrews, J. T., Jennings, A. E., Coleman, C. G., and Eberl, D., 2010: Holocene variations in mineral and grain-size composition along the East Greenland glaciated margin (ca $67-70^{\circ} \mathrm{N}$ ): local versus long-distant sediment transport. Quaternary Science Reviews, 29: 2619-2632.

Andrews, J. T. and Eberl, D. D., subm.: Determination of sediment provenance by the unmixing the mineralogies of $<2 \mathrm{~mm}$ source-area sediments

Axford, Y., Andresen, C., Andrews, J. T., Belt, S. T., Geirsdottir, A., Masse, G., Miller, G. H., Olafsdottir, S., and Vare, L. L., in press: Do paleoclimate proxies agree? Statistical comparison of climate and sea-ice reconstructions from Icelandic marine and lake sediments, 300-1900 AD. Journal Quaternary Research.

Bendle, J. A. P. and Rosell-Mele, A., 2007: High-resolution alkenone sea surface temperature variability on the North Icelandic Shelf: implications for Nordic Seas paleoclimatic development during the Holocene. The Holocene, 17: 9-24.

Bigg, G. R., 1999: An estimate of the flux of iceberg calving from Greenland. Arctic, Antarctic, and Alpine Research, 31: 174-178.

Bond, G., Heinrich, H., Broecker, W. S., Labeyrie, L., McManus, J., Andrews, J. T., Huon, S., Jantschik, R., Clasen, S., Simet, C., Tedesco, K., KLas, M., Bonani, G., and Ivy, S., 1992: Evidence for massive discharges of icebergs into the glacial Northern Atlantic. Nature, 360: 245-249.

Bond, G., Showers, W., Cheseby, M., Lotti, R., Almasi, P., deMenocal, P., Priore, P., Cullen, H., Hajdas, I., and Bonani, G., 1997: A Pervasive Millennial-Scale Cycle in North Atlantic Holocene and Glacial Climates. Science, 278: 1257-1266.

Brooks, C. K., 1990: Kangerdlugssuaq Studies: Processes at a Rifted Continental Margin: Geological Institute, Univ. of Copenhagen, 100 pp.

Clemens, S. C., 2005: Millennial-band climate spectrum resolved and linked to centennialscale solar cycles. Quaternary Science Reviews, 24: 521-531. 
Darby, D. A. and Bischoff, J. F., 1996: A statistical approach to source determination of lithic and Fe oxide grains: An example from the Alpha Ridge, Arctic Ocean. Journal of Sedimentology Research, 66: 599-607.

Darby, D. A., 2003: Sources of sediment found in the sea ice from the western Arctic Ocean, new insights into processes of entrainment and drift patterns. Journal of Geophysical Research, 108: 13-11 to 13-10. doi: 10, 1111029/1112002JC1001350, 1112003.

Darby, D. A. and Bischof, J., 2004: A Holocene record of changing Arctic Ocean ice drift analogous to the effects of the Arctic Oscilation. Palaeoceanography, 19: 1 of 9. doi: 10.1029/2003PA000961, 002004.

Darby, D. A., Ortiz, J., Polyak, L., Lund, S., Jakobsson, M., and Woodgate, R. A., 2009: The role of currents and sea ice in both slowly deposited central Arctic and rapidly deposited Chukchi-Alaskan margin sediments. Global Planetary Change., 68: 58-72, doi:10.1016/j.gloplacha.2009.1002.1007.

Dethleff, D., 2005: Entrainment and export of Laptev Sea ice sediments, Siberian Arctic (vol 110, art no C07009, 2005). Journal of Geophysical Research-Oceans, 110.

Dethleff, D. and Kuhlmann, G., 2009: Entrainment of fine-grained surface deposits into new ice in the southwestern Kara Sea, Siberian Arctic. Continental Shelf Research, 29: 691701.

Dethleff, D. and Kuhlmann, G., 2010: Fram Strait sea-ice sediment provenance based on silt and clay compositions identify Siberian and Kara and Laptev sxeas as main source reegions. Polar Research, 29: 265-282.

Divine, D. V. and Dick, C., 2006: Historical variability of the sea ice edge position in the Nordic Seas. Journal of Geophysical Research, 111: 1 of 14, doi:10.1029/2004JC002851.

Dowdeswell, J. A., 1986: The Distribution and Character of Sediments in a Tidewater Glacier, Southern Baffin Island, N.W.T., Canada. Arctic and Alpine Research, 18: 4546.

Dowdeswell, J. A., Whittington, R. J., and Hodgkins, R., 1992: The sizes, frequencies, and freeboards of East Greenland icebergs observed using ship radar and sextant. Journal Geophysical Research, 97: 3515-3528.

Dowdeswell, J. A., Whittington, R. J., and Marienfeld, P., 1994: The origin of massive diamicton facies by iceberg rafting and scouring, Scorsby Sund, East Greenland. Sedimentology, 41: 21-35.

Dowdeswell, J. A., Maslin, M. A., Andrews, J. T., and McCave, I. N., 1995: Iceberg production, debris rafting, and the extent and thickness of Heinrich layers $(\mathrm{H}-1, \mathrm{H}-$ 2) in North Atlantic sediments. Geology, 23: 301-304.

Dowdeswell, J. A., Evans, J., and Cofaigh, C. O., 2010: Submarine landforms and shallow acoustic stratigraphy of a $400 \mathrm{~km}$-long fjord-shelf-slope transect, Kangerlussuaq margin, East Greenland. Quaternary Science Reviews, 29: 3359-3369.

Dwyer, J. L., 1993: Monitoring Characteristics of Glaciation in the Kangerdlugssuaq Fjord Region, East Greenland, Using Digital LANDSAT MSS and TM Data. MSc, University of Colorado, Boulder. 238 pp.

Dwyer, J. L., 1995: Mapping tide-water glacier dynamics in East Greenland using Landsat data. Journal of Glaciology, 41: 584-596.

Dyke, A. S., England, J., Reimnitz, E., and Jette, H., 1997: Changes in Driftwood Delivery to the Canadian Arctic Archipelago: The Hypothesis of Postglacial Oscillations of the Transpolar Drift. Arctic, 50: 1-16. 
Eberl, D. D., 2003: User guide to RockJock: A program for determining quantitative mineralogy from X-ray diffraction data. United States Geological Survey, Open File Report 03-78, 40 pp, Washington, DC.

Eberl, D. D., 2004: Quantitative mineralogy of the Yukon River system: Variations with reach and season, and determining sediment provenance. American Mineralogist, 89: 1784-1794.

Eggertsson, O., 1993: Origin of the driftwood on the coasts of Iceland: A dendrochronological study. Jokull, 43: 15-32.

Eiriksson, J., Knudsen, K. L., Haflidason, H., and Henriksen, P., 2000: Late-glacial and Holocene paleoceanography of the North Iceland Shelf. Journal of Quaternary Science, 15: 23-42.

Evans, J., Dowdeswell, J. A., Grobe, H., Niessen, F., Stein, R., Hubberten, H.-W., and Whittington, R. J., 2002: Late Quaternary sedimentation in Kejser Joseph Fjord and the contiental margin of East Greenland. In Dowdeswell, J. A. and O'Cofaigh (eds.), Glacier-influenced sedimentation on High-Latitude conintental margins. London: Geological Society 149-179.

Farmer, G. L., Barber, D. C., and Andrews, J. T., 2003: Provenance of Late Quaternary iceproximal sediments in the North Atlantic: $\mathrm{Nd}, \mathrm{Sr}$ and $\mathrm{Pd}$ isotopic evidence. Earth and Planetary Science Letters, 209: 227-243.

Foldvik, A., Aagaard, K., and Torresen, T., 1988: On the velocity field of the East Greenland Current. Deep Sea Research, 35: 1335-1354.

Geirsdottir, A., Miller, G. H., Axford, Y., and Olafsdottir, S., 2009: Holocene and latest Pleistocene climate and glacier fluctuations in Iceland. Quaternary Science Reviews, 28: 2107-2118.

Ghil, M., Allen, M. R., Dettinger, M. D., Ide, K., Kondrashov, D., Mann, M. E., Roberston, A. W., Saunders, A., Tian, Y., Varadi, F., and Yiou, P., 2002: Advanced spectral methods for climatic time series. Reviews of Geophysics, 40: 3-1 to 3-41 1003, doi:1029/2000RG000092.

Giraudeau, J., Jennings, A. E., and Andrews, J. T., 2004: Timing and mechanisms of surface and intermediate water circulation changes in the Nordic Sea over the last 10,000 cal years: a view from the North Iceland shelf. Quaternary Science Reviews, 23: 21272139.

Gray, D., 1881a: Ice chart of the Arctic Ocean between Greenland and Spitsbergen. From observations by Capt. David Gray: Royal Geographical Society, Control \# 503747. Scale 503741:503746,503750,503000.

Gray, D., 1881b: The recent advance of the Polar ice in the Greenland and Spitzbergen Sea. Proceedings of the Royal Geographiocal Society and monthly record of Geography, 3: 740741.

Grousset, F. E., Labeyrie, L., Sinko, J. A., Cremer, M., Bond, G., Duprat, J., Cortijo, E., and Huon, S., 1993: Patterns of ice-rafted detritus in the glacial North Atlantic (40$\left.55^{\circ} \mathrm{N}\right)$. Paleoceanography, 8: 175-192.

Grousset, F. E., Pujol, C., Labeyrie, L., Auffret, G., and Boelaert, A., 2000: Were the North Atlantic Heinrich events triggered by the behavior of the European ice sheets. Geology, 28: 123-126.

Grousset, F. E., Cortijo, E., Huon, S., Herve, L., Richter, T., Burdloff, D., Duprat, J., and Weber, O., 2001: Zooming in on Heinrich layers. Paleoceanography, 16: 240-259. 
Hebbein, D., 2000: Flux of ice-rafted detritus from sea ice in the Fram Strait. Deep-Sea Research II, 47: 1773-1790.

Heinrich, H., 1988: Origin and consequences of cyclic ice rafting in the Northeast Atlantic Ocean during the past 130,000 years. Quat. Res., 29: 143-152.

Hemming, S., Vorren, T., and Kleman, J., 2002a: Provinciality of ice rafting in the North Atlantic: application of $40 \mathrm{Ar} / 39 \mathrm{Ar}$ dating of individual ice rafted hornblende grains. Quaternary International, 95-96: 75-85.

Hemming, S. R., Hall, C. M., Biscaye, P. E., Higgins, S. M., Bond, G. C., McManus, J. F., Barber, D. C., Andrews, J. T., and Broecker, W. S., 2002b: 40Ar/39Ar ages and 40Ar concentrations of Fine-Grained Sediment Fractions from North Atlantic Heinrich Layers. Chemical Geology, 182: 583-603.

Hemming, S. R., 2004: Heinrich Events: Massive late Pleistocene detritus layers of the North Atlantic and their global climate imprint. Reviews of Geophysics, 42: RG1005/2004.

Henriksen, H., 2008: Geological history of Greenland. Copenhagen: Geological Survey of Denmark and Greenland, 272 pp.

Hesse, R., 1995: Continental slope and basin sedimentation adjacent to an ice-margin: a continous sleeve-gun profile across the Labrador Slope, Rise and Basin. In Pickering, K. T. e. a. (ed.), Atlas of Deep Water Environments Architectural style in turbidite sytems, 14-17.

Hopkins, T. S., 1991: The GIN Sea- A synthesis of its physical oceanography and literature review 1972-1985. Earth Science Reviews, 30: 175-318.

Howat, I. M., Joughin, I., Fahnestock, M., Smith, B. E., and Scambos, T. A., 2008: Synchronous retreat and acceleration of southeast Greenland outlet glaciers 200006: ice dynamics and coupling to climate. Journal of Glaciology, 54: 646-660.

Jennings, A. E. and Weiner, N. J., 1996: Environmental change on eastern Greenland during the last 1300 years: Evidence from Foraminifera and Lithofacies in Nansen Fjord, $68^{\circ} \mathrm{N}$. The Holocene, 6: 179-191.

Jennings, A. E., Gronvold, K., Hilberman, R., Smith, M., and Hald, M., 2002: High resolution study of Icelandic tephras in the Kangerlussuaq Trough, southeast Greenland, during the last deglaciation. Journal of Quaternary Science, 17: 747-757.

Jennings, A. E., Andrews, J. T., and Wilson, L., 2011: Holocene environmental evolution of th SE Greenland Shelt north and south of the Denmark Strait: Irminger and East Greenland current interactions. Quaternary Science Reviews.

Kelly, M. A. and Lowell, T. V., 2009: Fluctuations of local glaciers in Greenland during the latest Pleistocene and Holocene time. Quaternary Science Reviews, 28: 2088-2106.

Koch, L., 1945: The East Greenland Ice. Meddelelser om Gronland, 130 (3): 346.

Kolla, V., Biscaye, P. E., and Hanley, A. F., 1979: Distribution of quartz in Late Quaternary sediments in relation to climate. Quaternary Research, 11: 261-277.

Kristjansdottir, G. B., Stoner, J. S., Gronvold, K., Andrews, J. T., and Jennings, A. E., 2007: Geochemistry of Holocene cryptotephras from the North Iceland Shelf (MD992269): Intercalibration with radiocarbon and paleomagnetic chronostratigraphies. The Holocene, 17: 155-176.

Kwok, R., 2009: Outflow of Arctic Ocean Sea Ice into the Greenland and Barents Seas: 19792007. Journal of Climate, 22: 2438-2457. 
Larsen, B., 1983: Geology of the Greenland-Iceland Ridge in the Denmark Strait. In Bott, M. H. P., Saxov, S., Talwani, M., and Thiede, J. (eds.), Structure and Development of the Greenland-Scotland Ridge. London: Plenum Publishing Corp., 425-444.

Lawson, D. E., Strasser, J. C., Evenson, E. B., Alley, R. B., Larson, G. J., and Arcone, S. A., 1998: Glaciohydraulic supercooling: a freeze-on mechanism to create stratified, debris-rich basal ice: I. Field Evidence. Journal of Glaciology, 44: 547-562.

Lebreiro, S. M., Moreno, J. C., McCave, I. N., and Weaver, P. P. E., 1996: Evidence for Heinrich layers off Portugal (Tore Seamount: 39N, 12W). Marine Geology, 131: 47-56.

Li, C., Battisti, D. S., and Bitz, C. M., 2010: Can North Atlantic Sea Ice Anomalies Account for Dansgaard-Oeschger Climate Signals? Journal of Climate, 23: 5457-5475.

MacAyeal, D. R., 1993: Binge/purge oscillations of the Laurentide Ice Sheet as a cause of North Atlantic's Heinrich events. Paleoceanography, 8: 775-784.

Malmberg, S.-A., 1985: The water masses between Iceland and Greenland. Journal Marine Research Institute, 9: 127-140.

Mann, M. E. and Lees, J. M., 1996: Robust estimation of background noise and signal detection in climatic time series. Climatic Change, 33: 409-445.

Marko, J. R., Fissel, D. B., Wadhams, P., Kelly, P. M., and Brown, R. D., 1994: Iceberg severity off Eastern North America---its relationship to sea-ice variability and climate change. Journal of Climate, 7: 1335-1351.

McCarty, D. K., 2002: Quantitative mineral analysis of clay-bearing mixtures: The "Reynolds Cup" contest. Innternational Union of Crystallography, Newsletter, No. 27: 12-16.

Miller, J. D. and Hotzel, I. S., 1984: Iceberg flux estimation in the Labrador Sea. International Offshore Mechanics and Arctic Engineering Symposium, 3rd, New Orleans, Louisiana, Feb. 12-17, 1984, 3: 298-304.

Moros, M., McManus, J., Rasmussen, T., Kuijpers, A., Dokken, T., Snowball, I., Nielsen, T., and Jansen, E., 2004: Quartz content and the quartz-to-plagioclase ratio determined by X-ray diffraction: a proxy for ice rafting in the northern North Atlantic? Earth and Planetary Science Letters, 218: 389-401.

Moros, M., Andrews, J. T., Eberl, D. D., and Jansen, E., 2006: The Holocene history of drift ice in the northern North Atlantic: Evidence for different spatial and temporal modes. Palaeoceanography, 21: 1 of 10. doi:10.1029/2005PA001214.

Mugford, R. I. and Dowdeswell, J. A., 2010: Modeling iceberg-rafted sedimentation in highlatitude fjord environments. Journal of Geophysical Research-Earth Surface, 115.

Mugford, R. I. and Dowdeswell, J. A., in press: Modeling glacial meltwater plume dynamics and sedimentation in high-latitude fjords. Journal of Geophysical Research.

Ogilvie, A. E. J., 1996: Sea-ice conditions off rhe coasts of Iceland A.D. 1601-1850 with special reference to part of the Maunder Minimum period (1675-1715). North European climate data in the latter part of the Maunder Minimum period A.D. 1675-1715, AmSVaria 25: 9-12.

Ogilvie, A. E. J. and Jonsdottir, I., 2000: Sea ice, climate, amd Icelandic fisheries in the eighteenth and nineteenth centuries. Arctic, 53: 383-394.

Ortiz, J. D., Polyak, L., Grebmeier, J. M., Darby, D., Eberl, D. D., Naidu, S., and Nof, D., 2009: Provenance of Holocene sediment on the Chukchi-Alaskan margin based on combined diffuse spectral reflectance and quantitative X-Ray Diffraction analysis. Global and Planetary Change, 68: 71-84. 
Paillard, D., Labeyrie, L., and Yiou, P., 1996: Macintosh Program Performs Time-Series Analysis. EOS, 77: 379.

Parkinson, C. L., 2000: recent trend reversals in Arctic sea ice extents: possible connection to the North Atlantic oscillation. Polar Geography, 24: 1-12.

Parkinson, C. L., Rind, D., Healy, R. J., and Martinson, D. G., 2001: The impact of sea ice concentration accuracies on climate model simulations with the GISS GCM. Journal of Climate, 14: 2606-2623.

Peck, V. L., Hall, I. R., Zahn, R., Grousset, F. E., Hemming, S. R., and Scourse, J. D., 2007: The relationship between Heinrich events and their European precursors over the past 60 ka BP: a mulit-proxy ice-rafted debris provenance study in the North East Atlantic. Quaternary Science Reviews, 26: 862-875.

Pirrung, M., Futtere, D., Grobe, H., Matthiessen, J., and Niessen, F., 2002: Magnetic susceptibility and ice-rafted debris in surface sediments of the Nordic Seas: Implications for Isotope Stage 3 oscillations. Geo-Marine Letters, 22: 1-11.

Principato, S. M., 2003: The late Quaternary history of eastern Vestfirdir, NW Iceland. PhD, Geological Sciences, University of Colorado, Boulder. $258 \mathrm{pp}$.

Reeh, N., Mayer, C., Miller, H., Thomsen, H. H., and Weidick, A., 1999: Present and past climate control on fjord glaciations in Greenland: Implications for IRD-deposition in the sea. Geophysical Research Letters, 26: 1039-1042.

Reeh, N., Thomsen, H. H., Higgins, A. K., and Weidick, A., 2001: Sea ice and the stability of north and northeast Greenland floating glaciers. In Jeffries, M. O. and Eicken, H. (eds.), Annals of Glaciology, 33, 474-480.

Reimnitz, E., Barnes, P. W., and Kempema, E. W., 1987: Anchor Ice, Seabed Freezing, and Sediment Dynamics in Shallow Arctic Seas. Journal of Geophysical Research, 92: 14, 671-614, 678.

Rogers, J. C., Yang, L., and Li, L., 2005: The role of Fram Strait winter cyclones on sea ice flux and on Spistbergen air temperatures. Geophysical Research Letters, 32: 1 of 4, doi:10.1029/2004GL022262.

Schmith, T. and Hanssen, C., 2003: Fram Strait ice export during the nineteenth and twentieth centuries reconstructed from a multiyear sea ice index from Southwestern Greenland. Journal of Climate, 16: 2782-2791.

Sigurdsson, F. H., 1969: Report on Sea Ice off the Icelandic Coasts October 1967 to September 1968. Jokull, 19: 77-93.

Smith, L. M. and Andrews, J. T., 2000: Sediment characteristics in iceberg dominated fjords, Kangerlussuaq region. East Greenland. Sedimentary Geology, 130: 11-25.

Smith, L. M., Alexander, C., and Jennings, A. E., 2002: Accumulation in East Greenland Fjords and on the continental shelves adjacent to the Denmark Strait over the last century based on $210 \mathrm{~Pb}$ geochronology. Arctic, 55: 109-122.

Stefansson, U., 1962: North Icelandic Waters. Rit Fiskideildar, III. Bind, Vol 3, 269 pp.

Stein, R., Dittmers, K., Fahl, K., Kraus, M., Matthiessen, J., Niessen, F., Pirrung, M., Polyakova, Y., Schoster, F., Steinke, T., and Futterer, D. K., 2004: Arctic (palaeo) river discharge and environmental change: evidence from the Holocene Kara Sea sedimentary record. Quaternary Science Reviews, 23: 1485-1511.

Stoner, J. S., Jennings, A. E., Kristjansdottir, G. B., Andrews, J. T., Dunhill, G., and Hardardottir, J., 2007: A paleomagnetic approach toward refining Holocene radiocarbon based chronostratigraphies: Paleoceanographic records from North 
Iceland (MD99-2269) and East Greenland (MD99-2322) margins. Palaeoceanography, 22: 1 0f 23. PA1209, doi:1210:1029/2006PA001285, 002007.

Stuiver, M., Reimer, P. J., Bard, E., Beck, J. W., Hughen, K. A., Kromer, B., McCormack, F. G., v.d. Plicht, J., and Spurk, M., 1998: INTCAL98 Radiocarbon age calibration 24,000-0 cal BP. Radiocarbon, 40: 1041-1083.

Syvitski, J. P. M., Andrews, J. T., and Dowdeswell, J. A., 1996: Sediment deposition in an iceberg-dominated Glacimarine Environment, East Greenland: Basin Fill Implications. Global and Planetary Change, 12: 251-270.

Syvitski, J. P. M., Stein, A., Andrews, J. T., and Milliman, J. D., 2001: Icebergs and seafloor of the East Greenland (Kangerlussuaq) continental margin. Arctic, Antarctic and Alpine Research, 33: 52-61.

Thompson, D. W. J. and Wallace, J. M., 1998: The Arctic oscillation signature in wintertime geopotential height and temperature fields. Geophysical Research Letters, 25: 12971300.

Tremblay, L. B., Mysak, L. A., and Dyke, A. S., 1997: Evidence from driftwood records for century-to-millennial scale variations of the high latitude atmospheric circulation during the Holocene. Geophysical Research Letters, 24: 2027-2030.

van den Broeke, M., Bamber, J., Ettema, J., Rignot, E., Schrama, E., van de Berg, W. J., van Meijgaard, E., Velicogna, I., and Wouters, B., 2009: Partitioning Recent Greenland Mass Loss. Science, 326: 984-986.

Verplanck, E. P., Farmer, G. L., Andrews, J., Dunhill, G., and Millo, C., 2009: Provenance of Quaternary glacial and glacimarine sediments along the southeast Greenland margin. Earth and Planetary Science Letters, 286: 52-62.

Wallevik, J. E. and Sigurjonsson, H., 1998: The Koch index: Formulation, corrections and extension. Icelandic Meteorological Office Report

Ward, C. R., Taylor, J. C., and Cohen, D. R., 1999: Quantitative mineraology of sandstones by X-ray diffractometry and normative analysis. Journal Sedimentary Research, 69: 10501062. 


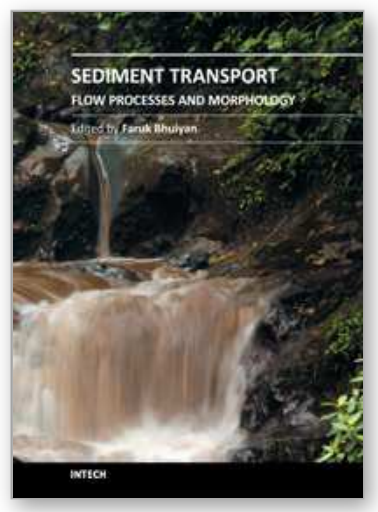

\section{Sediment Transport - Flow and Morphological Processes}

Edited by Prof. Faruk Bhuiyan

ISBN 978-953-307-374-3

Hard cover, 250 pages

Publisher InTech

Published online 26, October, 2011

Published in print edition October, 2011

The purpose of this book is to put together recent developments on sediment transport and morphological processes. There are twelve chapters in this book contributed by different authors who are currently involved in relevant research. First three chapters provide information on basic and advanced flow mechanisms including turbulence and movement of particles in water. Examples of computational procedures for sediment transport and morphological changes are given in the next five chapters. These include empirical predictions and numerical computations. Chapters nine and ten present some insights on environmental concerns with sediment transport. Last two contributions deal with two large-scale case studies related to changes in the transport and provenance of glacial marine sediments, and processes involving land slides.

\section{How to reference}

In order to correctly reference this scholarly work, feel free to copy and paste the following:

J.T. Andrews (2011). Unraveling Sediment Transport Along Glaciated Margins (the Northwestern Nordic Seas) Using Quantitative X-Ray Diffraction of Bulk (<2mm) Sediment, Sediment Transport - Flow and Morphological Processes, Prof. Faruk Bhuiyan (Ed.), ISBN: 978-953-307-374-3, InTech, Available from:

http://www.intechopen.com/books/sediment-transport-flow-and-morphological-processes/unraveling-sedimenttransport-along-glaciated-margins-the-northwestern-nordic-seas-using-quantitativ

\section{INTECH}

open science | open minds

\author{
InTech Europe \\ University Campus STeP Ri \\ Slavka Krautzeka 83/A \\ 51000 Rijeka, Croatia \\ Phone: +385 (51) 770447 \\ Fax: +385 (51) 686166 \\ www.intechopen.com
}

\author{
InTech China \\ Unit 405, Office Block, Hotel Equatorial Shanghai \\ No.65, Yan An Road (West), Shanghai, 200040, China \\ 中国上海市延安西路65号上海国际贵都大饭店办公楼405单元 \\ Phone: +86-21-62489820 \\ Fax: +86-21-62489821
}


(C) 2011 The Author(s). Licensee IntechOpen. This is an open access article distributed under the terms of the Creative Commons Attribution 3.0 License, which permits unrestricted use, distribution, and reproduction in any medium, provided the original work is properly cited. 